\title{
Evaluation of perennial lupin/cocksfoot pasture relative to lucerne pasture under summer dry conditions
}

\author{
A.D. BLACK and T.P. RYAN-SALTER \\ Field Research Centre, Faculty of Agriculture and Life Sciences, PO Box 85084, Lincoln University, Lincoln \\ 7647, Canterbury, New Zealand \\ alistair.black@lincoln.ac.nz
}

\begin{abstract}
The productivity of a perennial lupin/cocksfoot mix was compared to that of lucerne in summer dry conditions at Lincoln University, Canterbury, New Zealand. The pastures were planted in December 2013 and rotationally grazed by ewe lambs in autumn 2014 (Year 1), and by ewe hoggets in spring-summer and ewe lambs in autumn of 2014/2015 (Year 2) and 2015/2016 (Year 3). For lupin/cocksfoot relative to lucerne in Years 1 to 3, sheep liveweight gains were $54 \%$ of $107 \mathrm{~kg} / \mathrm{ha}, 68 \%$ of $1134 \mathrm{~kg} / \mathrm{ha}$ and $50 \%$ of 1347 $\mathrm{kg} / \mathrm{ha}$; herbage dry matter yields were $122 \%$ of 3520 $\mathrm{kg} / \mathrm{ha}, 64 \%$ of $10230 \mathrm{~kg} / \mathrm{ha}$ and $59 \%$ of $9680 \mathrm{~kg} / \mathrm{ha}$; and in Years 2 and 3, the water use efficiency of sheep liveweight gain was $76 \%$ of $2.0 \mathrm{~kg} / \mathrm{ha} / \mathrm{mm}$ and $49 \%$ of $2.7 \mathrm{~kg} / \mathrm{ha} / \mathrm{mm}$, respectively. The lupin content in the pre-grazing herbage in Years 1 to 3 averaged 42, 22 and $12 \%$, whereas the lucerne content averaged 78,95 and $98 \%$, respectively. This showed that perennial lupin was not persistent at this lowland site.
\end{abstract}

Keywords: Lupinus polyphyllus, Dactylis glomerata, Medicago sativa, dryland, sheep liveweight gain, water use

\section{Introduction}

Merino sheep farmers in New Zealand face an ongoing challenge to improve the efficiency and productivity of their high country farm systems. This challenge can be met, at least in part, by growing pasture legumes that are adapted to the difficult climatic and soil conditions. The expansion of the area planted in lucerne (Medicago sativa) is an obvious and widely adopted option, due to its deep taproot and ability to produce large amounts of high quality forage. However, lucerne is not suitable for many regions of the high country where low $\mathrm{pH}$ and high soluble aluminium in the subsoil restrict its root growth and nodulation (Douglas et al. 1987; Moir \& Moot 2010). Therefore, additional legume species are required to provide more nitrogen and higher quality forage than the current resident pastures.

Several lines of evidence indicate that perennial lupin (hybrid of Lupinus polyphyllus with other lupin species) is well adapted to summer dry, moderately fertile soils in the South Island high country (Jarvis et al. 1997; Scott 2001, 2014; White 1995; Woodman et al. 1996). A grazing trial at Mt John, Tekapo, showed that perennial lupin increased in abundance over 5 years to eventually produce more feed than traditionally used clovers (Trifolium pratense and Trifolium hybridum), resulting in greater liveweight gains per hectare of Merino wethers set stocked on these pastures (Scott et al. 1994). This improvement was despite a lower feeding value for perennial lupin due to its alkaloid content (Gibbs 1988). The nutritional value of perennial lupin for sheep has also been quantified at a lowland site at Lincoln, Canterbury (Kitessa 1992; Kitessa et al. 1993). However, there have been few commercial plantings of perennial lupin in the high country.

The overall aim of this research programme was to evaluate and develop the full potential of perennial lupin as a viable pasture species for high country farms. The performance of Merino ewes and their lambs grazing perennial lupin was quantified at Sawdon Station, Tekapo (Black et al. 2014). The ability of perennial lupin to form an effective symbiosis with resident rhizobia populations was also confirmed (Ryan-Salter et al. 2014). At the same time, perennial lupin was successfully established at Glenmore Station, Tekapo, on low $\mathrm{pH}$ soil without lime and with cocksfoot (Dactylis glomerata) as a companion species (Moot \& Pollock 2014). However, limited seed supply (Monk et al. 2016) and debate about planting perennial lupin in the high country (Wardle 2016), continues to restrict its uptake.

To complement the previous high country work, a study was set up at Lincoln University, Canterbury, to compare the sheep liveweight yield, herbage yield and water use efficiency of a perennial lupin/cocksfoot pasture mix against that of lucerne pasture as a positive control.

\section{Methods}

\section{Site and preparation}

The two pasture types were compared at the Horticultural Research Area at Lincoln University, Canterbury, New Zealand ( $43^{\circ} 38^{\prime} 53^{\prime \prime} \mathrm{S}, 172^{\circ} 27^{\prime} 24^{\prime \prime}$ E, $9 \mathrm{~m}$ a.s.1.). The soil type was a Templeton silt loam overlying alluvial gravel (Cox 1978), with a $\mathrm{pH}$ of 6.0, Olsen $\mathrm{P}$ of 17 $\mathrm{mg} /$ litre and sulphate $\mathrm{S}$ of $1 \mathrm{mg} / \mathrm{kg}$ in the top $7.5 \mathrm{~cm}$. 


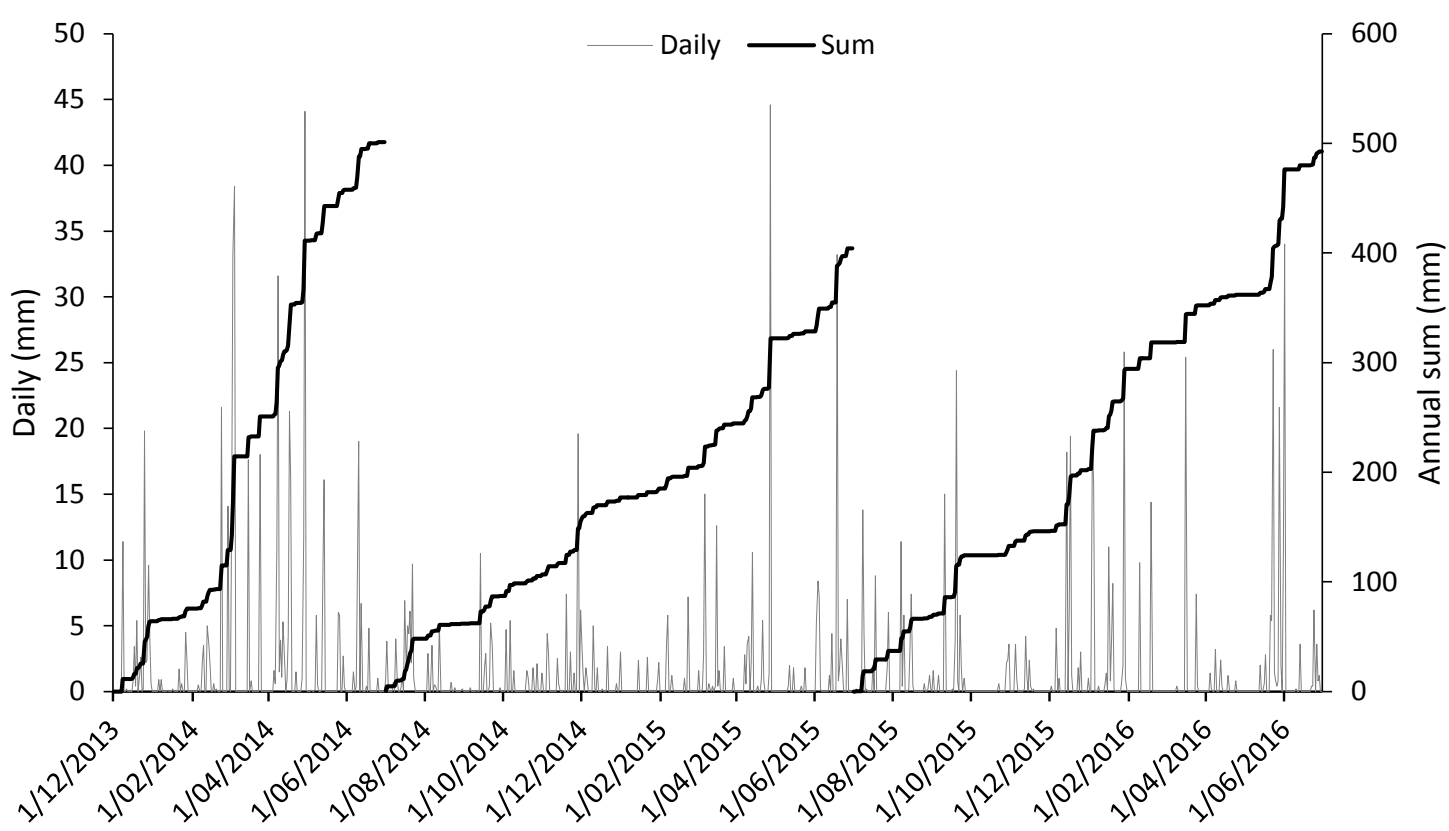

Figure 1 Rainfall during the study period (5 December 2013 - 30 June 2016) from Broadfields meteorological station, located 2 km north of the experimental site at Lincoln University, Canterbury.

Rainfall data for the study period (5 December 2013 30 June 2016) are presented in Figure 1.

The study site was a 2 ha paddock that had been in grass/clover pasture (a mix of mostly Lolium perenne and Trifolium repens) and then one crop of forage oats (Avena sativa). The oats were harvested for baleage in October 2013 and the paddock was irrigated (about 50 $\mathrm{mm}$ over 2 weeks), ploughed and tilled into a seedbed in November 2013. The rectangular paddock was then divided along its longest axis into three replicate blocks of $59 \times 90 \mathrm{~m}$, each block was divided into two plots of $29.5 \times 90 \mathrm{~m}$, or $0.26 \mathrm{ha}$, and the two pasture types were randomly allocated to the two plots within each block.

\section{Plant material}

Perennial lupin was supplied by Rosavear \& Co. Ltd., Ashburton, New Zealand, from a local commercial grower. Two varieties were used and they are colloquially referred to as 'blue' and 'Russell' by the seed supplier (Moot \& Pollock 2014). This 'blue', perennial lupin should not to be confused with annual 'blue lupin' (Lupinus angustifolius), which is a commonly planted forage lupin. The Russell lupin seeds were mostly derived from collections of roadside populations of the multi-coloured flower horticultural lupin hybrid Lupinus polyphyllus $\times$ Lupinus arboreus, and likely includes genetic material from other lupin species (Edward 2003). On the day before planting the lupin seed was scarified and inoculated with Group G Bradyrhizobium inoculant, which had been recommended for Lupinus angustifolius in New Zealand (BASF, Auckland, New Zealand) and was effective on perennial lupin (Ryan-Salter et al. 2014).

The cocksfoot cultivar was Kara (supplied by Agricom, New Zealand) and the lucerne cultivar was SF Force 4 (Seed Force, New Zealand).

\section{Pasture establishment}

The two pasture types were sown on 5 December 2013 using a precision drill fitted with coulters spaced 0.15 $\mathrm{m}$ apart (Flexiseeder, Christchurch, New Zealand). The seeding rates were $30 \mathrm{~kg} / \mathrm{ha}$ of lupin (a 50:50 mix of both varieties) mixed with $10 \mathrm{~kg} / \mathrm{ha}$ of cocksfoot, and the lucerne pasture was sown at $15 \mathrm{~kg} / \mathrm{ha}$. Irrigation (about $50 \mathrm{~mm}$ over 2 weeks) was applied in February 2014 to aid pasture establishment. Each plot was then fenced with permanent wire netting fences and plumbed with a portable water trough. A raceway along the western boundary connected all plots to a small corral. Each plot was subdivided along its longest axis into five small paddocks of equal area (0.052 ha) using temporary electric fences to allow a group of sheep to rotationally graze within each plot. No fertiliser was applied at establishment.

\section{Sheep}

In Year 1 (5 December 2013 - 30 June 2014), Merino ewe lambs were used as the biological indicator of pasture performance. They were brought down from Sawdon Station and grazed the plots from 11 March to 
19 May 2014 (69 days), before being taken back there because several sheep developed hoof problems.

In Year 2 (1 July 2014 - 30 June 2015), ewe hoggets and ewe lambs from Lincoln University's Ashley Dene Farm were used. These sheep were from the Beef + Lamb New Zealand Central Progeny Test (CPT; McLean et al. 2006) and were of variable breed percentages incorporating Romney, Coopworth, Perendale, Corriedale, Texel maternal and Growbulk. The hoggets were put onto the treatments in spring when the average herbage mass was about $2000 \mathrm{~kg}$ of dry matter (DM)/ha; 5 August for lupin/cocksfoot and 15 September for lucerne. All hoggets were shorn on 28 November and replaced with the ewe lambs on 18 February. Those lambs grazed the plots until 29 May, giving a total grazing period of 297 days for lupin/ cocksfoot and 256 days for lucerne.

In Year 3 (1 July 2015 - 30 June 2016), ewe hoggets from the Ashley Dene flock of the CPT, which had the same breed composition as the sheep used in the previous year, were put onto both pastures on 3 September. They were shorn on 24 November and taken off the plots on 11-14 March. Then Coopworth stud ewe lambs from Ashley Dene were used and they grazed on the plots from 17 March to 20 May, giving a total grazing period of 260 days for both pasture types.

For each cohort, 18-30 sheep were selected as 'core' sheep to determine their liveweight gain. Those sheep were blocked on initial liveweight and breed and one sheep from each block was randomly allocated to each plot, giving three to five core sheep per plot. All sheep were given an anthelmintic treatment before entering the plots.

\section{Management}

The sheep were rotationally stocked on the five small paddocks within each plot. Each paddock was grazed in series and all groups of sheep were shifted to the next paddock in the rotation on the same day, except in spring 2014, when there were two grazing rotations for perennial lupin/cocksfoot from 5 August - 20 October and one grazing rotation for lucerne from 15 September - 20 October.

The number of sheep in a group (mean 5, range 2-10) and how many days they spent in a paddock (mean 9 days, range 4-15 days) were adjusted for pasture growth rate and mass to maintain a similar herbage allowance (approximately $2-3 \mathrm{~kg} \mathrm{DM} /$ head/day) for both pasture types. The mob size was altered using a 'Put and Take' policy where additional sheep could be added or removed from the group of core sheep assigned to the plot, when the group was moved to the next paddock. Both treatments were spelled for the winter when the herbage mass of a treatment was no longer sufficient to maintain feeding levels required of the core sheep.
When necessary, paddocks were mown to 4-5 $\mathrm{cm}$ above ground level immediately after the sheep were taken out to maintain the two pasture types at a similar vegetative growth stage. The plots were neither irrigated nor fertilised in Years 2 and 3.

\section{Measurements}

The sheep were weighed unfasted whenever they were put into or taken out of a paddock. Sheep liveweight yield $(\mathrm{kg} / \mathrm{ha})$ was calculated as the change in average liveweight of the core sheep since the previous measurement $\times$ the total number of sheep in the group divided by the area of the plot ( $0.26 \mathrm{ha})$. Grazing days was the total number of sheep in the group $\times$ how many days they spent in the paddock divided by 0.26 . These values were summed over time within years to calculate the annual liveweight yield and annual grazing days for each plot. The average daily sheep liveweight gain was calculated as annual liveweight yield divided by annual grazing days.

Herbage mass was measured in each of the 30 small paddocks each day the sheep were shifted and every 2-3 weeks in winter. For each paddock sheep were to be moved into, and for each paddock sheep were to be taken out of, herbage mass was estimated by cutting one or two $0.5 \mathrm{~m}^{2}$ quadrats to $1-2 \mathrm{~cm}$ above ground level using battery-powered clippers, and drying the cut samples for 2 days at $70^{\circ} \mathrm{C}$ in a force-draft oven. To estimate the DM content and botanical composition of the herbage on offer, each pre-grazing quadrat sample was weighed fresh and a subsample was separated into leaves plus petioles, stems and flowers of the sown legume, leaves plus sheaths and stems of cocksfoot, weeds and dead matter, before drying. For the other paddocks, herbage mass was estimated using a sward stick (Jenquip, Feilding, New Zealand) calibrated for each pasture type and for each regrowth interval using the pre- and post-grazing herbage mass data. If a paddock was mown after the sheep were taken out, its herbage mass was measured again immediately after mowing using the above methods.

Herbage yield was calculated as the change in herbage mass of a paddock since the previous measurement, assumed to be zero when the paddock was being grazed, and summed for each year. Herbage allowance was pregrazing herbage mass $\times$ the area of the paddock $(0.052$ ha) divided by the number of sheep and the number of days in the paddock. Apparent herbage intake was pregrazing herbage mass minus post-grazing herbage mass $\times 0.052$ divided by the number of sheep and number of days.

The nutritional value of the herbage offered to the sheep was estimated by grinding the dried pregrazing samples and analysing them for metabolisable energy (ME) and crude protein (CP) by near infrared 
reflectance spectroscopy (NIRS). This method required calibration of the NIRS system for perennial lupin (Jiang et al. 2014)

Soil moisture content was measured in one paddock (Paddock 2) per plot each day the sheep were shifted and every 2 weeks in winter. It was measured in the top $0.2 \mathrm{~m}$ using a time domain reflectometer (Trace System, Soil Moisture Equipment, USA) and at 10 $\mathrm{cm}$ layers from $0.2 \mathrm{~m}$ to $2.3 \mathrm{~m}$ depth using a neutron probe (Troxler, USA). The first readings were taken on 20 August 2014. Water use was calculated as rainfall minus the change in soil moisture content since the previous measurement and summed for each year. Water use efficiency was expressed as annual sheep liveweight yield divided by annual water use and as annual herbage yield divided by annual water use.

\section{Data analysis}

The response variables were tested for significant $(\alpha=0.05)$ differences between the two pasture types for each year by one-way analysis of variance in Genstat 18 software.

\section{Results and Discussion}

The lupin/cocksfoot mix produced, annually, 50-68\% as much sheep liveweight as the lucerne (Table 1). In Year 1, its liveweight yield in Merino lambs was 54\%

Table 1 Liveweight yield (LWY), grazing days (GD) and average daily liveweight gain (ADLWG) of young sheep grazing on a perennial lupin/cocksfoot pasture mix compared to lucerne over 3 years, under dryland conditions at Lincoln University, Canterbury.

\begin{tabular}{|c|c|c|c|}
\hline & $\begin{array}{c}\text { LWY } \\
\text { (kg/ha) }\end{array}$ & $\begin{array}{c}\text { GD } \\
\text { (sheep*days/ha) }\end{array}$ & $\begin{array}{c}\text { ADLWG } \\
\text { (g/head/day) }\end{array}$ \\
\hline & \multicolumn{3}{|c|}{ Year 1 (5 December 2013 - 30 June 2014) } \\
\hline Lupin/cocksfoot & 58 & 1997 & 29 \\
\hline Lucerne & 107 & 1790 & 60 \\
\hline$P$ value & 0.034 & 0.078 & 0.008 \\
\hline \multirow[t]{2}{*}{ SED } & 9.3 & 61.5 & 2.8 \\
\hline & \multicolumn{3}{|c|}{ Year 2 (1 July 2014 - 30 June 2015) } \\
\hline Lupin/cocksfoot & 768 & 4210 & 183 \\
\hline Lucerne & 1134 & 4528 & 251 \\
\hline$P$ value & 0.007 & 0.328 & 0.010 \\
\hline \multirow[t]{2}{*}{ SED } & 31.0 & 247.9 & 6.8 \\
\hline & \multicolumn{3}{|c|}{ Year 3 (1 July 2015 - 30 June 2016) } \\
\hline Lupin/cocksfoot & 674 & 3847 & 175 \\
\hline Lucerne & 1347 & 5101 & 264 \\
\hline$P$ value & 0.033 & 0.003 & 0.060 \\
\hline SED & 125.1 & 63.5 & 22.6 \\
\hline
\end{tabular}

of the $107 \mathrm{~kg} / \mathrm{ha}$ of lamb liveweight produced from lucerne $(\mathrm{P}<0.05)$. This was due to similar grazing days and slower $(\mathrm{P}<0.01)$ average daily liveweight gains. In Year 2, when CPT sheep were used to quantify pasture performance, the liveweight yield of lupin/cocksfoot was $68 \%$ of $1134 \mathrm{~kg} / \mathrm{ha}$ from lucerne $(\mathrm{P}<0.01)$, and this difference was again the result of similar grazing days and slower $(\mathrm{P}<0.01)$ average daily liveweight gains. In Year 3, lupin/cocksfoot pasture produced half as much liveweight as the $1347 \mathrm{~kg} / \mathrm{ha}$ from lucerne $(\mathrm{P}<0.05)$, but this difference was now due to fewer grazing days $(\mathrm{P}<0.01)$ with weak statistical evidence of slower average daily liveweight gains $(\mathrm{P}=0.060)$.

The grazing days on the two treatments (Table 1) reflected their herbage yields and the amount of feed offered to the sheep (Table 2). In Year 1, lupin/ cocksfoot yielded $780 \mathrm{~kg} \mathrm{DM} / \mathrm{ha}$ or $22 \%$ more herbage than lucerne $(\mathrm{P}<0.01)$. However, that difference was due to greater yields between planting and the first grazing, because the average pre-grazing herbage mass was similar for both treatments (Table 2). In Years 2 and 3, lupin/cocksfoot produced 64 and $59 \%$ as much herbage as lucerne $(\mathrm{P}<0.001)$, respectively, which led to less pre-grazing herbage mass $(\mathrm{P}<0.001$; Table 2$)$ and the fewer grazing days (Table 1 ). These differences in herbage yield between lupin/cocksfoot and lucerne, and the sheep liveweight gain results (Table 1), are consistent with those previously found between lucerne and cocksfoot-dominant pastures with traditional legumes, such as white clover and subterranean clover (Trifolium subterraneum), in a long-term sheep grazing experiment under similar dryland conditions at Lincoln University (Mills et al. 2014, 2015).

The differences in sheep daily liveweight gains between the two pasture types can be explained using the herbage intake (Table 2), composition (Figure 2) and nutritional value (Table 3) results. Estimating the herbage intake of grazing animals can be difficult, but it is possible to estimate 'apparent' intake by quantifying the amount of feed offered (pre-grazing herbage mass) and comparing it to the amount of feed refused (post-grazing herbage mass). In the autumn of Year 1, apparent herbage intakes were similar for both treatments, while the post-grazing herbage mass was lower for lucerne $(\mathrm{P}<0.01)$, suggesting that the slower Merino lamb growth rates on lupin/cocksfoot (Table 1) may have been due to differences in herbage composition and nutritional value. In Years 2 and 3, herbage intakes by sheep on lupin/cocksfoot were lower than on lucerne ( $68 \%$ of $1.7 \mathrm{~kg} \mathrm{DM} /$ head/day), and this would have contributed to their slower growth rates. The lower intake of lupin/cocksfoot herbage in Year 2 was despite a similar post-grazing herbage mass and herbage allowance (Table 2), whereas in Year 3, it was possibly also because of a lower post-grazing herbage 
mass $(\mathrm{P}<0.001)$ and herbage allowance $(\mathrm{P}<0.001)$ for lupin/cocksfoot compared to lucerne. The latter result was unexpected because the grazing management aimed to maintain a similar herbage allowance for both treatments.

The herbage offered to the sheep was similar in DM content but differed in botanical and morphological composition between the two pasture types (Figure 2 ). The lupin content in the pre-grazing herbage of lupin/cocksfoot in Years 1, 2 and 3 averaged 42, 22 and $12 \%$ respectively, whereas the lucerne content averaged 78,95 and $98 \%$, respectively $(\mathrm{P}<0.001)$. In both pasture types, the weed content was mostly fathen (Chenopodium album) in Year 1 and broad-leaved dock (Rumex obtusifolius) and volunteer white clover in Years 2 and 3 (data not shown). The lupin herbage averaged $98 \%$ leaf and petiole and $2 \%$ stem and flower, compared to the lucerne herbage which averaged $60 \%$

Table 2 Herbage DM yield (HY), pre-grazing (PreG) and post-grazing (PostG) herbage mass (HM), herbage allowance (HA) and apparent herbage intake $(\mathrm{HI})$ of young sheep grazing on a perennial lupin/cocksfoot pasture mix compared to lucerne over 3 years, under dryland conditions at Lincoln University, Canterbury.

\begin{tabular}{|c|c|c|c|c|c|}
\hline & $\begin{array}{c}\text { HY } \\
\text { (kg DM/ha) }\end{array}$ & $\begin{array}{c}\text { PreG HM } \\
\text { (kg DM/ha) }\end{array}$ & $\begin{array}{l}\text { PostG HM } \\
\text { (kg DM/ha) }\end{array}$ & $\begin{array}{l}\text { HA (kg DM } \\
\text { /head/day) }\end{array}$ & $\begin{array}{r}\text { HI (kg DM } \\
\text { /head/day) }\end{array}$ \\
\hline & \multicolumn{5}{|c|}{ Year 1 (5 December 2013 - 30 June 2014) } \\
\hline Lupin/cocksfoot & 4300 & 2520 & 1550 & 1.9 & 0.8 \\
\hline Lucerne & 3520 & 2110 & 970 & 1.9 & 1.0 \\
\hline$P$ value & 0.003 & 0.150 & 0.007 & 0.484 & 0.118 \\
\hline \multirow[t]{2}{*}{ SED } & 239 & 279 & 204 & 0.12 & 0.13 \\
\hline & \multicolumn{5}{|c|}{ Year 2 (1 July 2014 - 30 June 2015) } \\
\hline Lupin/cocksfoot & 6570 & 1870 & 1030 & 2.9 & 1.2 \\
\hline Lucerne & 10230 & 2590 & 1010 & 3.1 & 1.8 \\
\hline$P$ value & $<0.001$ & $<0.001$ & 0.784 & 0.148 & $<0.001$ \\
\hline \multirow[t]{2}{*}{ SED } & 838 & 145 & 73 & 0.16 & 0.15 \\
\hline & \multicolumn{5}{|c|}{ Year 3 (1 July 2015 - 30 June 2016) } \\
\hline Lupin/cocksfoot & 4000 & 1390 & 620 & 2.0 & 1.1 \\
\hline Lucerne & 9680 & 2400 & 870 & 2.5 & 1.6 \\
\hline$P$ value & $<0.001$ & $<0.001$ & $<0.001$ & $<0.001$ & $<0.001$ \\
\hline SED & 452 & 115 & 63 & 0.11 & 0.08 \\
\hline
\end{tabular}

Table 3 Metabolisable energy (ME) and crude protein (CP) content of the pre-grazing herbage of a perennial lupin/cocksfoot pasture mix compared to lucerne averaged over 3 years, under dryland conditions at Lincoln University, Canterbury.

\begin{tabular}{|c|c|c|c|c|c|c|c|}
\hline & \multirow[t]{2}{*}{ Total herbage } & \multicolumn{3}{|c|}{ Legume } & \multicolumn{2}{|c|}{ Cocksfoot } & \multirow[t]{2}{*}{ Dead } \\
\hline & & $\begin{array}{c}\text { Leaf } \\
\text { and } \\
\text { petiole }\end{array}$ & Stem & Flower & $\begin{array}{c}\text { Leaf } \\
\text { and } \\
\text { sheath }\end{array}$ & Stem & \\
\hline & \multicolumn{7}{|l|}{ ME (MJ/kg DM) } \\
\hline Lupin/cocksfoot & 10.5 & 11.8 & 11.3 & 12.2 & 11.3 & 8.6 & 7.7 \\
\hline Lucerne & 9.9 & 11.7 & 9.2 & 11.8 & - & - & 6.9 \\
\hline$P$ value & 0.005 & 0.227 & 0.009 & 0.380 & - & - & 0.177 \\
\hline \multirow[t]{2}{*}{ SED } & 0.19 & 0.10 & 0.73 & 0.30 & - & - & 0.58 \\
\hline & CP (\%) & & & & & & \\
\hline Lupin/cocksfoot & 14.3 & 21.8 & 14.2 & 25.0 & 16.5 & 7.9 & 9.7 \\
\hline Lucerne & 19.2 & 25.4 & 13.5 & 19.4 & - & - & 11.7 \\
\hline$P$ value & $<0.001$ & $<0.001$ & 0.765 & 0.002 & - & - & 0.087 \\
\hline SED & 0.84 & 0.79 & 2.18 & 0.56 & - & - & 1.13 \\
\hline
\end{tabular}




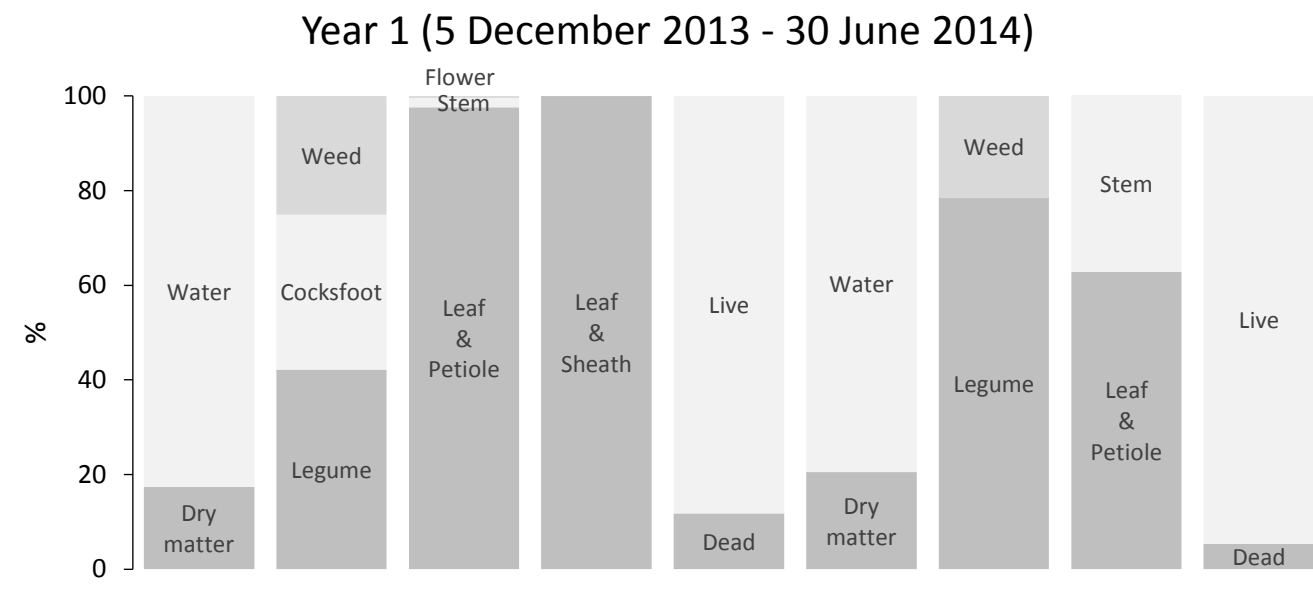

Year 2 (1 July 2014 - 30 June 2015)

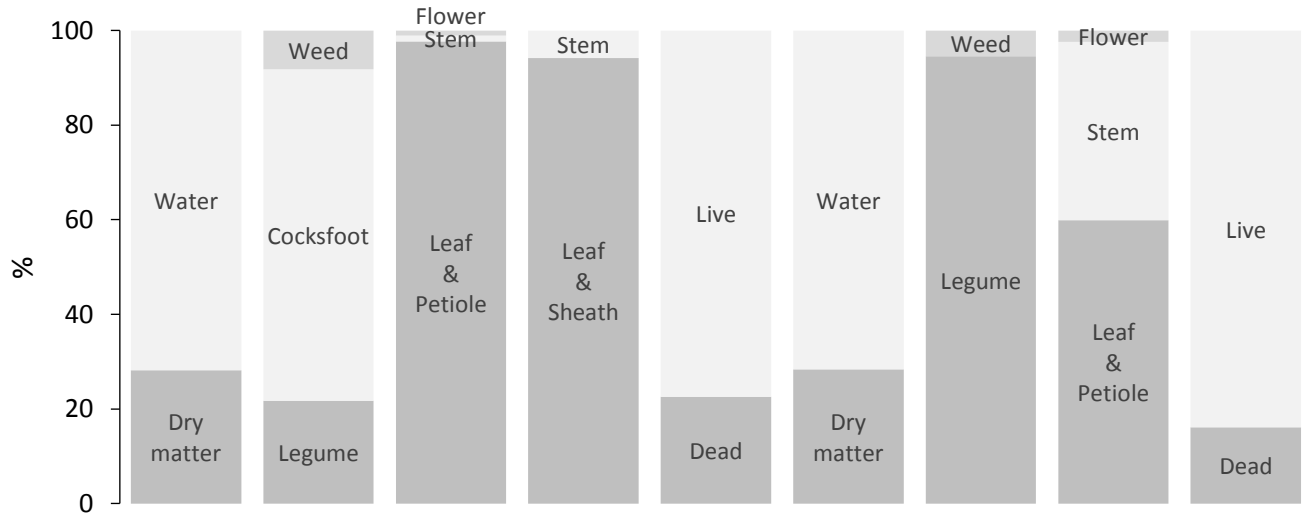

Year 3 (1 July 2015 - 30 June 2016)

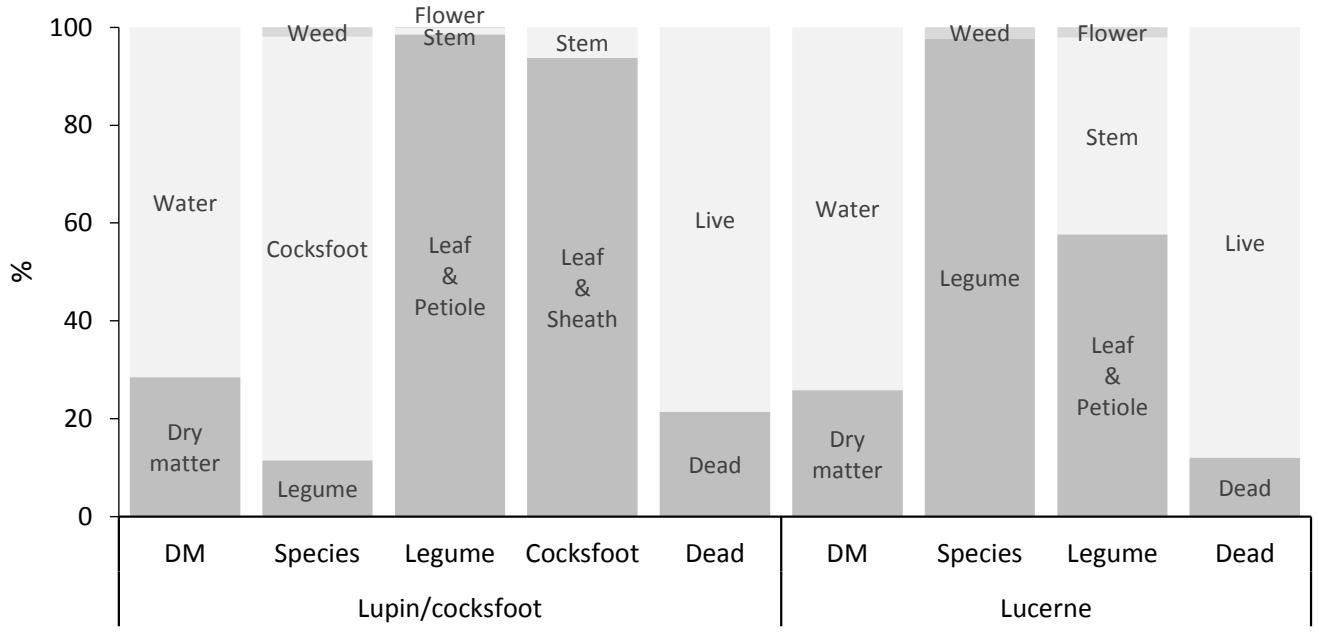

Figure 2 Dry matter (DM) (\% of fresh matter) and botanical composition (\% of DM) of the pre-graze herbage of a perennial lupin/ cocksfoot pasture mix compared to lucerne over 3 years, under dryland conditions at Lincoln University, Canterbury. 
leaf and petiole, 38\% stem and $2 \%$ flower. The cocksfoot herbage was mostly leaf and sheath material, and the dead matter content of the total herbage was higher for lupin/cocksfoot than lucerne $(\mathrm{P}<0.05)$. However, the lupin content appeared to halve each year and this was the result of the death of lupin plants. The reason for this plant death was not confirmed, but crown and root rot caused by Fusarium heterosporum Nees has been recognised as a possible cause of plant death in other field

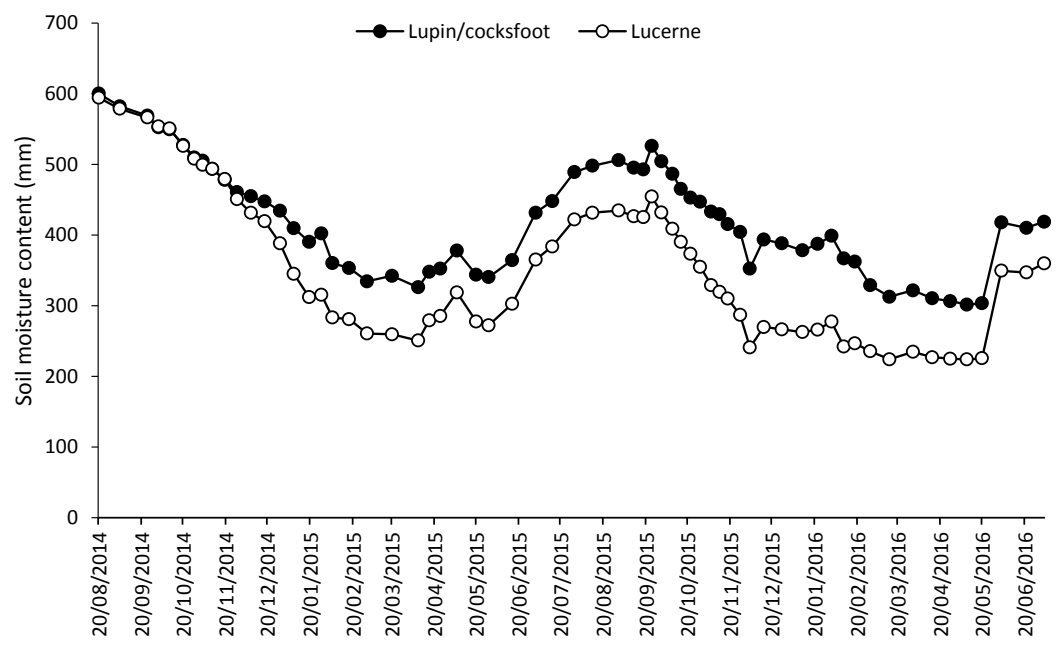

Figure 3 Soil moisture content to $2.3 \mathrm{~m}$ depth of a perennial lupin/cocksfoot pasture mix compared to lucerne over 2 years, under dryland conditions at Lincoln University, Canterbury. experiments with Russell

lupin at Lincoln, where lupin populations were reduced over 2 years by disease (Kitessa 1992; Harvey et al. 1996).

The nutritional value analyses indicated that the total herbage offered to the sheep on lupin/cocksfoot was higher in $\mathrm{ME}(\mathrm{P}<0.01)$ and lower in $\mathrm{CP}(\mathrm{P}<0.001)$ than the total herbage offered to the sheep on lucerne (Table 3). The leaf plus petiole fraction of the lupin had a similar ME value and a lower $\mathrm{CP}$ content $(\mathrm{P}<0.001)$ than the leaf plus petiole fraction of lucerne, whereas the stems of lupin had a higher ME value $(\mathrm{P}<0.01)$ and a similar $\mathrm{CP}$ content to the stems of lucerne. These nutritional values for perennial lupin were consistent with values that Black et al. (2014) and others (Kitessa 1992; Kitessa et al. 1993) have reported previously. The leaf plus sheath matter of cocksfoot appeared to have a similar ME value and a lower CP content to the leaves plus petioles of both legumes, while the stems of cocksfoot and the dead matter had the lowest ME and $\mathrm{CP}$ content. However, the pre-grazing herbage mass (Table 2) and botanical composition (Figure 2) data indicated that there was less high ME, high CP legume herbage available to the sheep on lupin/cocksfoot than there was available on lucerne. Therefore, the sheep on lupin/cocksfoot may have had less opportunity to select high quality components in their diet, and this may have contributed to their lower average daily liveweight gains compared to those on lucerne.

The serial soil moisture readings taken in Years 2 and 3 indicated that the soil moisture content to $2.3 \mathrm{~m}$ depth was higher for lupin/cocksfoot than lucerne from November 2014 to June 2016 (Figure 3). Averaged over both years, the minimum soil moisture content was $314 \mathrm{~mm}$ for lupin/cocksfoot compared with 237 $\mathrm{mm}$ for lucerne, and these minimums were reached in April/May each year. However, plant water use was not significantly different between the two pasture types (Table 4) despite the differences in sheep liveweight (Table 1) and herbage (Table 2) yields. This meant that, in Year 2, the water use efficiency of sheep liveweight gain for lupin/cocksfoot was $76 \%$ of the $2.0 \mathrm{~kg} \mathrm{LW} / \mathrm{ha} /$ $\mathrm{mm}$ of water used for lucerne $(\mathrm{P}<0.05)$, and there was weak statistical evidence that the water use efficiency of herbage yield for lupin/cocksfoot was $71 \%$ of lucerne's $17.9 \mathrm{~kg} \mathrm{DM} / \mathrm{ha} / \mathrm{mm}(\mathrm{P}=0.063)$. In Year 3, the water use efficiency of liveweight gain for lupin/ cocksfoot was $49 \%$ of the $2.7 \mathrm{~kg} \mathrm{LW} / \mathrm{ha} / \mathrm{mm}$ for lucerne

Table 4 Water use (WU) and water use efficiency (WUE) of sheep liveweight yield (LWY) and herbage DM yield (HY) for a perennial lupin/cocksfoot pasture mix compared to lucerne over 2 years, under dryland conditions at Lincoln University, Canterbury.

\begin{tabular}{|c|c|c|c|}
\hline & $\begin{array}{l}\text { WU } \\
(\mathrm{mm})\end{array}$ & $\begin{array}{l}\text { WUE of LWY } \\
\text { (kg LW/ha/mm) }\end{array}$ & $\begin{array}{c}\text { WUE of HY } \\
\text { (kg DM/ha/mm) }\end{array}$ \\
\hline & \multicolumn{3}{|c|}{ Year 2 (1 July 2014 - 30 June 2015) } \\
\hline Lupin/cocksfoot & 512 & 1.5 & 12.8 \\
\hline Lucerne & 573 & 2.0 & 17.9 \\
\hline$P$ value & 0.238 & 0.026 & 0.063 \\
\hline \multirow[t]{2}{*}{ SED } & 36.5 & 0.08 & 1.40 \\
\hline & \multicolumn{3}{|c|}{ Year 3 (1 July 2015 - 30 June 2016) } \\
\hline Lupin/cocksfoot & 505 & 1.3 & 7.9 \\
\hline Lucerne & 498 & 2.7 & 19.4 \\
\hline$P$ value & 0.566 & 0.026 & 0.002 \\
\hline SED & 11.0 & 0.23 & 0.50 \\
\hline
\end{tabular}


$(\mathrm{P}<0.05)$, and the water use efficiency of herbage yield for lupin/cocksfoot was $41 \%$ of $19.4 \mathrm{~kg} \mathrm{DM} / \mathrm{ha} / \mathrm{mm}$ for lucerne $(\mathrm{P}<0.01)$. Moot et al. (2008) also reported cocksfoot-dominant pastures as being less efficient users of soil moisture compared to lucerne in summer dry conditions.

\section{Conclusions}

The lupin/cocksfoot mix was $50-70 \%$ as productive as lucerne for sheep liveweight yield (50-68\%) and herbage yield (59-64\%), and it appeared to use soil water less efficiently as the lucerne, during Years 2 and 3 of the comparison. The lupin content of the mix halved each year due to the death of lupin plants, which resulted in the mix being dominated by cocksfoot after 3 years. This showed that the perennial lupin did not persist at this lowland site and as a result the lupin/ cocksfoot mix did not appear to perform any better than cocksfoot-dominant pastures with traditional legumes in summer dry conditions.

\section{ACKNOWLEDGEMENTS}

We are grateful for the New Zealand Merino Company Ltd., Struthers Trust, Sinclair Cummings Trust and Alexander Agribusiness scholarships received by Ryan-Salter. We also thank Dan Dash, Dave Jack and Keith Pollock for technical assistance.

\section{REFERENCES}

Black, A.D.; Loxton, G.; Ryan-Salter, T.P.; Moot, D.J. 2014. Sheep performance on perennial lupins over three years at Sawdon Station, Lake Tekapo. Proceedings of the New Zealand Grassland Association 76: 35-40.

Cox, J.E. 1978. Soils and agriculture of part Paparua County, Canterbury, New Zealand. New Zealand Soil Bureau Bulletin No. 34. New Zealand Department of Scientific and Industrial Research, Wellington. 128 pp.

Douglas, M.H.; Brash, D.W.; Barratt, B.I.P.; Keoghan, J.M. 1987. Successful lucerne growing in inland Otago. Proceedings of the New Zealand Grassland Association 48: 193-197.

Edward, P. 2003. The Russell lupin story. National Council for the Conservation of Plants and Gardens. $48 \mathrm{pp}$.

Gibbs, H.M. 1988. Variation in alkaloid content of Russell lupins and L. arboreus. Bachelor of Horticultural Science Honours dissertation. University of Canterbury (Lincoln College).

Harvey, I.C.; Seyb, A.M.; Warren, A.F.J.; Van Den Ende, H. 1996. The biological control of Russell lupin in riverbeds with endemic plant pathogens. pp. 119-125. In: Proceedings 49th New Zealand Plant Protection Conference.
Jarvis, P.; Lucas, R.J.; White, J.G.H. 1997. Sulphur and phosphorus responses of Russell lupin in rangeland. pp. 21-22. In: Proceedings of the 18th International Grasslands Congress.

Jiang, S.; Keaney, D.; Ryan-Salter, T.P.; Black, A.D. 2014. Developing NIRS calibrations to predict the nutritional value of Russell lupin (Lupinus polyphyllus). 16th Australian Near Infrared Spectroscopy Group Conference, Coffs Harbour, NSW.

Kitessa, S.M. 1992. The nutritional value of Russell lupin (Lupinus polyphyllus $x$ Lupinus arboreus) for sheep. Masters thesis. Lincoln University.

Kitessa, S.M.; Hill, G.D.; Nicol, A.M. 1993. Yield, composition and in-vitro digestibility of Russell lupin. pp. 1801-1802. In: Proceedings of the 17th International Grasslands Congress.

McLean, N.J.; Jopson, N.B.; Campbell, A.W.; Knowler, K.; Behrent, M.; Cruickshank, G.; Logan, C.M.; Muir, P.D.; Wilson, T.; McEwan, J.C. 2006. An evaluation of sheep meat genetics in New Zealand: The central progeny test (CPT). Proceedings of the New Zealand Society of Animal Production 66: 368-372.

Mills, A.; Lucas, R.J.; Moot, D.J. 2014. 'MaxClover' grazing experiment: I. Annual yields, botanical composition and growth rates of six dryland pastures over nine years. Grass and Forage Science 70: 557570.

Mills, A.; Lucas, R.J.; Moot, D.J. 2015. 'MaxClover' grazing experiment II: sheep liveweight production from six grazed dryland pastures over 8 years. New Zealand Journal of Agricultural Research 58: 57-77.

Moir, J.L.; Moot, D.J. 2010. Soil pH, exchangeable aluminium and lucerne yield responses to lime in a South Island high country soil. Proceedings of the New Zealand Grassland Association 72: 191-196.

Monk, S.; Moot, D.J.; Belgrave, B.; Rolston, M.P.; Caradus, J.R. 2016. Availability of seed for hill country adapted forage legumes. Hill Country Symposium. Grassland Research and Practice Series 16: 257-267.

Moot, D.J.; Brown, H.E.; Pollock, K.M.; Mills, A. 2008. Yield and water use of temperate pastures in summer dry environments. Proceedings of the New Zealand Grassland Association 70: 51-57.

Moot, D.J.; Pollock, K.M. 2014. Perennial lupin establishment and yield when sown at five different rates at Glenmore Station, Lake Tekapo. Proceedings of the New Zealand Grassland Association 76: 5359.

Ryan-Salter, T.P.; Black, A.D.; Andrews, M.; Moot, D.J. 2014. Identification and effectiveness of rhizobial strains that nodulate Lupinus polyphyllus. Proceedings of the New Zealand Grassland Association 76: 61-65. 
Scott, D. 2001. Sustainability of New Zealand highcountry pastures under contrasting development inputs 7. Environmental gradients, plant species selection, and diversity. New Zealand Journal of Agricultural Research 44: 59-90.

Scott, D. 2014. The rise to dominance over two decades of Lupinus polyphyllus among pasture mixtures in tussock grassland trials. Proceedings of the New Zealand Grassland Association 76: 47-52.

Scott, D.; Maunsell, L.A.; Hunt, L.M. 1994. Relative sheep liveweight gain on perennial lupin, red clover and alsike. Proceedings of the New Zealand Grassland Association 56: 155-157.
Wardle, P. 2016. War of the Lupins. New Zealand Geographic 137: 32-41.

White, J.G.H. 1995. A review of legume introduction in tussock grasslands with particular reference to species tolerant of low nutrient inputs. Proceedings of the Agronomy Society of New Zealand 25: 7785.

Woodman, R.F.; Keoghan, J.M.; Allan, B.E. 1996. Pasture legumes for the drought-prone, outwash soils of the southern Mackenzie Basin. Proceedings of the New Zealand Grassland Association 58: 247-252. 
